REVISTA de

PEDAGOGIE

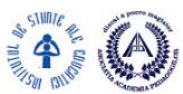

JOURNAL of

PEDAGOGY

http://revped.ise.ro

Print ISSN 0034-8678; Online ISSN: 2559 - 639X

\title{
CONTRASTIVE-COMPARATIVE STUDY ON STUDENTS' PERCEPTIONS OF USING LITERARY TEXTS AS AUTHENTIC LANGUAGE LEARNING RESOURCES
}

STUDIU COMPARATIV PRIVIND PERCEPŢIA ELEVILOR DESPRE UTILIZAREA TEXTELOR LITERARE CA RESURSE AUTENTICE DE ÎNVĂTARE A LIMBILOR STRĂINE

\section{Lilia PETRICIUC}

Journal of Pedagogy, 2019 (1), 123 - 138

https://doi.org/10.26755/RevPed/2019.1/123

The online version of this article can be found at: http://revped.ise.ro/category/2019-en/

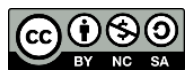

This work is licensed under the Creative Commons Attribution-NonCommercial-ShareAlike 4.0 International License. To view a copy of this license, visit http://creativecommons.org/licenses/by-nc-sa/4.0/ or send a letter to Creative Commons, PO Box 1866, Mountain View, CA 94042, USA.

Published by:

\section{INSTITUTUL DE ȘTIINTTE ALE EDUCAȚIEI}

http://www.ise.ro/

Further information about Revista de Pedagogie - Journal of Pedagogy can be found at:

Editorial Policy: http://revped.ise.ro/editorial-policy/

Author Guidelines: http://revped.ise.ro/the-writer-guide-2/ 


\title{
CONTRASTIVE-COMPARATIVE STUDY ON STUDENTS' PERCEPTIONS OF USING LITERARY TEXTS AS AUTHENTIC LANGUAGE LEARNING RESOURCES
}

\author{
Lilia Petriciuc* \\ State Pedagogical University "Ion Creangă”, \\ Chişinău, Republic of Moldova \\ to.li@live.com
}

\begin{abstract}
This comparative study represents an attempt to identify students' perceptions and needs at the same time, in terms of incorporating literary texts in the foreign language class. For quite a long time literary texts (LT) have been massively marginalized as a language learning resource and consequently students display significant deficiencies in interpreting figurative language, making inferences, thinking critically. The researcher assumes that revitalizing LT in the language class would bring multiple benefits to the students who learn EFL as part of a double program training them to become teachers of other subjects as well as primary and secondary school teachers in Moldova. It is a contrastive-comparative study involving 83 students, 48 undergraduates from the University of Granada and 35 from SPU "Ion Creangă" of Chişinău, Moldova. The data were collected through mixed instruments: all of the students filled in a survey for quantitative data and the students from Moldova participated in a semi-structured interview at the end of their 2nd year course in English. The findings reveal rather positive attitudes in favor of LT as a language learning resource, but at the same time there are differences between the perceptions of Spanish and Moldovan students. The pedagogical implications of the study for stakeholders at "Ion Creangă" University suggest reconsidering the EFL curriculum with a view of incorporating more LT alongside other types of authentic materials used to develop students' language proficiency.
\end{abstract}

Keywords: attitudes and perceptions, authentic materials, benefits, differences, literary texts.

* Senior Lecturer, State Pedagogical University “Ion Creangă”, Chişinău, Republic of Moldova. 


\section{Rezumat}

Studiul dat reprezintă o încercare de a identifica atitudinea, dar şi trebuin ele celor ce studiază limba engleză ca limbă străină (LES) vis-a-vis de utilizarea textelor literare (TL) în calitate de resursă didactică autentică. Pentru o perioadă destul de însemnată textul literar a fost marginalizat în con inuturile curriculare de limbă engleză, ceea ce a condus la formarea defectuoasă a competen elor lor de comunicare, în special în ceea ce ine de decodarea şi interpretarea limbajului figurat, a face inferen e şi a gândi critic. Considerăm că revitalizarea TL va aduce multiple beneficii instructiv-educative celor ce studiază LES ca parte a programului cu dublă specializare, în formarea lor ca profesori de istorie, pedagogie, limbă română şi limbă engleză pentru învă ământul primar sau gimnazial. Studiul contrastiv-comparativ a implicat 83 de responden $i$, dintre care 48 studen $i$ ai Facultă ii de Ştiin e ale Educa iei de la Universitatea din Granada, Spania şi 35 de la aceeaşi Facultate a Universită ii Pedagogice „Ion Creangă” din Chişinău. Datele ob inute prin desfăşurarea sondajului de opinie şi a unui interviu, relevă percep ii diferite: deşi admit multitudinea de beneficii educa ionale a TL, studen ii spanioli sunt destul de reticen $i$ referitor la exploatarea lor ca resursă didactică pentru dezvoltarea competen elor lor de comunicare în LE, iar cei moldoveni sus in ini iativa de a încorpora TL în curriculumul de LE, alături de alte genuri de texte. Factorii de decizie de la Universitatea Pedagogică „Ion Creangă” ar trebui să ină cont de constatările date ca temei pentru poten iale modificări în curriculumul de LES.

Cuvinte-cheie: atitudini şi percep ii, beneficii, diferen e, materiale autentice, texte literare.

\section{Context}

Education in Moldova has undergone a series of reforms lately, some of which have proven effective and some others not quite so. The country is still in its transition to adopting and implementing international standards at all levels and education is among the vulnerable domains that require immediate and constant attention. The reforms implemented at lower levels of the educational system seem to be more functional than at higher levels. Ever since Moldova joined the Bologna Process, the stakeholders are making sustainable efforts to upgrade educational programs to train high quality professionals for the national and international labour market. In this context, teacher training programs at universities have been upgraded and renewed to meet the requirements of the never-ending changes in our society. English 
as a foreign language is taught in almost all teacher training programs, for different periods of time. In this case, I am not going to refer to any of the programs at the Department of Foreign Languages and Literatures, but mainly to those programs training primary school teachers of English, or the double programs like History and English or Pedagogy and English.

Although specialized literature in the field of EFL has witnessed a significant awareness increase related to the need of integrating literary texts in the language curriculum, there is still much reluctance to do it, for a number of reasons. At "Ion Creangă" University, pre-service teachers of EFL to primary school learners do not have much opportunity to interact with LT on the grounds that they are not going to teach literature or that LT are by far too complex and require too much time to cover. In the current context, with English being highly commercialized and those learning it requiring immediate results, LTs have gradually been ousted from many university language learning programs. The exclusion has inevitably generated a number of deficiencies in students' level of language proficiency and general culture. The researcher believes that future teachers need extensive interaction with different types of language input, particularly literary texts, which are notorious for bringing numerous educational benefits, alongside linguistic ones.

Learning English as a foreign language is a real endeavor for Moldova's students as there are limited opportunities for them to expand their competencies outside the classroom and obviously, the majority have difficulties when interacting in English with users of some other language, despite their pretty good level of linguistic competence. There are a number of English Language courses, but none of them contains any reference to including literary texts. On the contrary, LT have been massively rejected from any instructional content on the assumption that they are too complex, too sophisticated and do not reflect students' communicative needs. The key argument against LT in the EFL curriculum in these programs referred to their outdated character and students' needs, which meant that they should be able to use the language communicatively instead of "doing literature". The only opportunity to explore a literary text is given to them in their final semester at the university, several months before graduation. It is a 30-hour course called Literary Text Analysis. Ongoing class observation and semi-structured interviews revealed that the students displayed major 
deficiencies in dealing with a LT ranging from decoding figurative language to drawing inferences and thinking critically. The students themselves acknowledged their incapacity of getting to grips with LT, although they all stated it was very interesting for them and extremely useful for their overall communicative competence in English inquiring why the course was so brief. They emphasized their need and eagerness of having more hours allotted to LT and not only in their final semester, but much earlier.

The class observation and the students' remark led to the next move: conducting surveys among students from non-philological departments to identify their needs and perceptions in terms of authentic texts in general, and of literary texts in particular. They have been dealing with other types of authentic texts alongside inauthentic ones previously, but these have been mainly informative like excerpts from newspapers, magazines or YouTube videos. In this respect, the texts selected were always interesting and caught their attention entirely with students being involved in a wide range of communicative activities. Nonetheless, there was always a sense of something missing "to make the picture complete".

The referential texts used to study the language are suitable if the students are expected to develop language skills that would ensure they pass an exam or get a certain job. In our particular case, the students are pre-service teachers and we strongly believe that having skills to deal with any kind of text is a must. Besides, the course-books used in primary and secondary school in Moldova contain an extensive number of literary texts, which should serve as another argument in favor of re-incorporating LT in the mainstream Curriculum for EFL at this level. Though the students will not major as philologists, we believe that as teachers they should have extensive knowledge of how to approach LT for language acquisition purposes.

Globally speaking, while conducting lesson observation, it was pretty simple to notice that their previous interactions with English relied heavily on expanding their linguistic competence, without enough emphasis on the other components of the $\mathrm{CC}$, notwithstanding the global acknowledgement that language cannot function without culture and vice-versa. Additionally, the students had major deficiencies when it came to creative writing, which indicated that the referential texts they used as contents for linguistic acquisition were not enough to facilitate it. Henceforward, a change in 
contents and approaches is imminent and fully grounded from a practical and theoretical perspective.

\section{Literature Review}

"Although literature occupies a place in some advanced ESL courses, literary texts, which could permit us to achieve many important goals for a wide range of mature ESL students, remain largely neglected and they do not enjoy the resurgence of attention we might expect" (Gajdusek, p.227). Taking into account Gajdusek's viewpoint, we will share her conception of literature as used in the language classroom: "Here, literature is used to denote original-not adapted fairly short, and fairly contemporary fiction, poetry, and drama of the target culture."(ibd). Since English nowadays does not belong to any particular country, it implicitly means that it could encompass any original piece of writing in English, notwithstanding what part of the world it comes from. Incorporating literature in EFL classrooms does not mean just the canonical texts belonging to the great classics. What we mean is literature with a small "l", according to MacRae (1996), which nowadays has come to include adverts, slogans, song lyrics, graffiti and any other original text that is created on the basis of some representation.

Despite the claim forwarded by an increasing number of researchers who state that LT are resurrected and we are witnessing their coming back into EFL curricula, especially due to concerns over the apparent international decline in reading and writing standards, (Xerri \& Xerri, 2012, p.18) we would like to note that the majority of mainstream course-books currently in vogue and many educational programs still reject it from their contents. And, to quote Sivasubramaniam's words (2006) this contemporary emphasis on course-books seems to be monopolizing English classrooms all over the world, promoting a reductionist view of language learning and hindering students from experiencing the imaginative content of literary texts (pp. 254-255). An explanation to this rejection could be found in the idea that the term literature in the language class is over-generalized to refer to the classics, instead of being used as an umbrella term to include a wide range of contents (song lyrics, sketches, short stories, poems, etc.) alongside a huge number of different activities to engage the learners and promote language acquisition. 
Another reason for repudiating TL from the language classroom is found in Collie and Slater's wording: literature was thought as embodying a static convoluted kind of language, far removed from the utterances of daily communication and "was seen as carrying an undesirable freight of cultural connotations" (1897, p.2). A similar view is shared by Guillian Lazar, who, analyzing literary discourse comparing its features with non-literary language use, states that literature does not constitute a particular type of language in itself, but that it may reveal a higher incidence of certain kinds of linguistic features which are tightly patterned in the text, as metaphors, similes, and assonance are extensively used in different other forms of discourse (1993, p. 7).

Literature has manifold outstanding benefits for the learners of a language. Undeniably, it is the best source of vocabulary enrichment. Students explore the language in a variety of contexts, styles, and registers, which are different from the strict formal or quasi formal style characteristic of referential texts. When dealing with a literary text, the students get in contact with figurative language, irony and sarcasm, which are not as pertinent in referential texts. Critics of LT as a language resource claim that these are overloaded with metaphorical language and sophisticated structures, it is worth noting that these are natural characteristics of human communication: figurative language is excessively present in daily conversations, starting from the most trivial ones about weather (It's raining cats and dogs, It's boiling hot!) to more formal ones like pillar of society, a weak/strong economy and so forth.)

A further strong argument for bringing the LT back to language classes resides in the fact that English nowadays does not belong to a single nation; it is a "global language", as David Crystal (2003) notes, featuring an extensive number of variations which could be presented to EFL learners through LT belonging to writers from different parts of the world reflecting pluri-linguistic and pluri-cultural trends of modern times.

The most frequent imputation refers to its extremely complex structures and sophisticated vocabulary and to the idea that learners are supposed to already have a strong grip of the language intricacies. The opponents to using LT as a language learning resource should most probably realize that the objective is not to study literature, but to exploit it to study the language in its many forms of use against usage. Although many textbook writers claim they included mainly authentic texts in the contents of the course book, it is 
hardly ever so since these materials are selected with the purpose of introducing some language structures as Collie and Slater point out (1987, p.3)

Authors like Collie and Slater (1987, 1996), McRae (1996), Savvidou, C. (2004), Van (2009), Alemi, M. (2010, 2013), Khatib, M. (2011), Das, B.B. (2014), Ortells, E. (2013), Paran A. (2006), Duff, P. A. (2001), Bobkina, H. (2014) have identified an extensive number of instructional benefits LT may bring into the language class, sharing the belief it can be a powerful pedagogical tool (Savvidou, 2004) and supplementing other types of contents with LT will provide the students with a more holistic language experience (Xerri \& Xerri, 2012, p.18)

G. Lazar (1996) lists six major educational benefits that LT can bring in the language class: motivating material, access to cultural background, encouraging language acquisition, expanding students' language awareness, developing students' interpretative abilities, and educating the whole person. Literary texts are excellent sources of motivation, since they involve the readers' emotions "giving them a sense of involvement" in the subject-matter (Lazar, 1993), a dimension the mainstream course book fails to attain, as they are focused on promoting a consumer's pattern of language in use with almost no consideration paid to emotional intelligence and other values that make us Human. The way we incorporate texts into the language class depends greatly on our students' level of language proficiency, but even at lower levels these can be successfully used for language practice and mostly for fostering their emotional intelligence and inculcating human values like sympathy, compassion, empathy, and tolerance. At higher levels of proficiency, the shift could be made to develop other skills like critical thinking and creative writing.

Literature is authentic texts as they are "real life texts" not written for pedagogic purposes.

The literary texts, if properly used, can serve as a very powerful tool for developing all the language skills (listening, speaking, reading, and writing) and it is obviously relevant for both teachers and course book writers to adopt this perspective, in view with Maley's words who emphasizes that it all depends on the purpose for which literature is being used. What matters here is to make a distinction between the study of literature and the use of 
literature as a resource for language teaching (Maley, apud Lazar, 1993, p.13).

The manifold benefits LT bring in educational contexts outweigh the drawbacks some harsh critics hurdle at them. Interacting with LT belonging to various writers from a number of cultures will most certainly expand the learners' worldviews and develop their intercultural competence and have a positive impact on their empathy and tolerance levels (Amer, 2003, p. 63). In line with Amer (2003) we posit that a syllabus that incorporates both representational and referential texts provides more opportunities for diversity and challenges the learners' critical thinking skills alongside developing their communicative competence in the target language. One of the many benefits highlighted by Collie and Slater (1987) refers to the potential of LT to increase readers' awareness of and ability "to cope with language intended for native speakers and thus they get additional familiarity with many different linguistic uses, forms and conventions of the written mode: with irony, exposition, argument, narration, and so on".

In these authors' opinion, LT "provides a rich context in which individual lexical or syntactic items are made memorable" thus highlighting the potential for linguistic and discourse competence development. Apart from it, when interacting with LT, learners explore an immense variety of language patterns in use, styles and registers, which gradually, upon repeated encounters, will become internalized and hopefully transformed into output, as components of their sociolinguistic competence in target language.

Apart from the advantages listed above, LT contributes considerably to the development of interpretative and critical thinking skills, which are essential tools in dealing with everyday situations. Though extremely demanding upon the reader at times, well-chosen LT will prove incredibly rewarding in the language class and beyond, since they serve to supply learners with many useful skills to help them tackle different situations. It is perfectly true that not all literary texts are suitable for classroom interaction and not all language they might contain is relevant for studies, nevertheless, there is always a choice to be made from among the huge ocean of literary works available nowadays which can be done in keeping with many aspects: time available, historical period, topics of interest, readability, pertinence, etc. 
For example, Costello (1990) emphasizes the positive impact LT has on learners and deems it "an invaluable adjunct to ESL composition, especially when teaching units are built on reading selections that are contemporary and challenging. And as reading comprehension improves, so does mastery of grammar, rhetoric, and Western culture" (p. 22).

Another benefit LT brings to learners of English, which is absolutely relevant to young adults, refers to tapping into their ability to transcend the text itself, to connect their own experiences to the ones described by the author, thus gaining a deeper insight and understanding of their own identity as belonging to a society, group, community, culture, etc. As a teacher, I strongly believe and identify my teaching creed with Erkaya's viewpoint "that literature can be used to reinforce language skills and complement teaching" (Erkaya, 2005, p.3). Cultural enrichment, which is in line with all language learning theories and the recommendations contained in the CEFR can be successfully attained through judiciously selected LT. Interacting with literature belonging to different geographical areas and historical periods not only contributes to expanding the students' knowledge of culture, but also plays a crucial role in opening their minds to change and diversity (Moecharam, 2014). Obviously, the advantages a literary piece of writing could bring into the language classroom outweigh by far its drawbacks and even if it means that there is an extra effort for the teacher, it is definitely worth it: short term, there might be a feeling of Sisyphean task, but long term, the outcomes will be absolutely rewarding.

\section{Study design and instruments}

This is a diagnosis study, as part of a larger research project, aiming at identifying the students' needs and perceptions with respect to introducing LT as supplementary content to their communicative EFL university course. The survey aims at identifying their perceptions about exploiting LT regularly, alongside other types of authentic materials in their learning English as a foreign language. Additionally, I intend to compare Moldovan students' perceptions with those from Spain to determine if there are significant differences and to what factors these might be attributed, pursuing the objective of revitalizing LTs in EFL teacher training programs in Moldova. 
The aim of this study is to identify if students really do not need literary texts to expand their horizons and boost their Communicative Competence (CC) in English. The research questions we are aiming to answer include:

- What is their perception of AT, particularly LT, in the language classroom?

- How do they react to dealing with poetry, drama, short stories as a way of linguistic and cultural development?

- Do they believe that their overall CC can be influenced by the study of literature?

- Are there significant differences between students' perceptions at the University of Granada (UGR) and those of State Pedagogical University "Ion Creangă” of Chişinău (SPU “Ion Creangă”)?

The study consisted of ten questions and the students were to provide answers to reflect their position using a 5 units Likert-type scale where 1 - strongly disagree, 2 - disagree, 3 - undecided, 4 - agree, 5 - strongly agree.

The first 3 questions referred to the use of authentic texts as a broad category and the other 7 were focused on exploiting literary texts as a language learning resource more specifically.

\section{Participants}

Participating in an Erasmus $\mathrm{K}+$ program at the University of Granada, the researcher, considered it relevant to conduct a comparative study to identify if students belonging to different geographical, economical, and sociocultural areas have similar or opposing views with regards to exploring LTs as an authentic language learning resource.

The participants in the survey were 48 second-year students from the University of Granada and 35 from State Pedagogical University "Ion Creangă" of Chişinău. The informants represent a random sample from the Sciences of Education departments, all pursuing more or less similar academic programs training to become primary school teachers, teachers of History and Geography. They have been studying English for 8,4 years on average and their age range was 19-22. 


\section{Data Collection}

At the UGR the paper-based questionnaire was administered at the beginning of a lecture to insure high attendance rates and participation in a short amount of time. Those from SPU "Ion Creangă" were given the survey to complete at home and bring it back to their teachers on the following day. Some students from Moldova got it via email and had to fill it in and send it back to the researcher some days later for plausible reasons. It has to be noted that the informants have had quite limited exposure to literary texts in their contact with the foreign language. Sporadically, they have explored some short stories and pieces of poetry and never dealt with drama within the classroom. However, during a short interview that preceded the survey, they admitted to have read different types of LT on their own, mainly for personal enjoyment. So, they were familiar with what literary texts in English entail and they could explain what difficulties they had to face when reading texts that they did not usually work with in class.

\section{Data Processing and Findings}

Considering the data yielded by the UGR students, it appears that even if they admit that LT can bring a lot of benefits in the language class, with $54,16 \%$ voting agree and $20,83 \%$ opting for strongly agree, nevertheless they do not seem enthusiastic about expanding their language skills through literature, with only $20,85 \%$ expressing agreement followed by a modest $6,25 \%$ who chose strongly agree (which accounts for just 3 students out of 48). A strikingly impressive number of the respondents indicated that $47,91 \%$ agree and $25 \%$ strongly agree that LT provide an authentic context for the teaching of grammar and vocabulary. More than half of the students from SPU "Ion Creangă" share the same belief: 34,28\% agree and 31,42\% strongly agree.

A curious fact is that, on the one hand, such a high percentage of the UGR students believe that LT provide an authentic context for the teaching of grammar and vocabulary and bring benefits to the learners, but on the other, they express their unwillingness to expand their language horizons through LT on a regular basis (items 4 and 5). Just 10,41\% chose agree as contrasted 
to $56,26 \%$ who disagree and $16,66 \%$ who strongly disagree. Though there were not many confusing answers like this, nevertheless it indicates two possible scenarios: either the students filled in the survey without giving it much consideration, or, without really understanding what using LT for language acquisition purposes entails.

$20 \%$ of the SPU "Ion Creangă" respondents expressed their strong agreement to exploiting LT as a language learning resource, supported by $24,28 \%$ who agree to it. The number of those who reject the idea is rather high, with $13,72 \%$ strongly disagreeing and $18,57 \%$ disagreeing. When compared to the UGR respondents' option, rejection level in much lower, but still rather high. Additionally, the undecided represents a significant proportion, 16,66\% UGR and 22,85\% SPU "Ion Creangă". Their indecisiveness could have a number of different underlying reasons, which should be looked into in deeper study. Undoubtedly, their choices might greatly depend on previous experiences with LT. If they studied some extremely difficult piece of literature, then they probably reckon that all literary texts are burdensome and impossible to use as a language learning resource.

Item 7 revealed some quite surprising fact: for $10,41 \%$ (strongly disagree) and 31,25\% (disagree) UGR students and SPU "Ion Creangă" with 11,42 \% (strongly disagree) and 20\% (disagree) responded that language complexity does not represent and impediment for them to interact with literature. On the other extreme, there is a significant difference between the two samples: only $6,25 \%$ of UGR admit language level is a challenge for them as contrasted to $27,41 \%$ of SPU "Ion Creangă" respondents.

The respondents from the two institutions differ greatly in their perceptions of literature as a source of cultural enrichment: $31,33 \%$ strongly agree and $34,28 \%$ agree as contrasted to $8,33 \%$ and respectively $18,8 \%$.

Considering all the data, the researcher considers that the respondents from the two institutions involved in the survey display a wide array of different perceptions in terms of using AT and more specifically LT as a source of language education. Altogether, the UGR students indicate they are not too eager to consider LT as a source of authentic language input, though they admit it might bring considerable benefits with $39,58 \%$ of them agreeing 
followed by $10,41 \%$ who strongly agree that the study of literature educates the whole person in a way that other functional approaches to language teaching do not (item 10).

Students from SPU “Ion Creangă” supplied data which lead to the conclusion that they are open and willing to develop their language skills through literature, with $44,58 \%$ of them agreeing and $14,75 \%$ strongly agreeing to the perspective (item 5) as contrasted to $8,57 \%$ who strongly disagree and $14,4 \%$ disagree.

\section{Limitations of the study and some negative aspects}

It appears that UGR students are more reserved about expanding their language proficiency through LT as it was seen from their responses: reject the use of LT as a language learning resource, though they absolutely agree that learning the language with authentic texts is paramount (item1). An explanation to this position could reside in the fact that the students who took the survey were studying ESP as part of their specialization and an important majority were young men. The Moldavan students participating in this survey were $98 \%$ young females and, as it is well known, there is a difference of tastes in terms of literature between genders. Most obviously, same gender participants would have provided more similar answers. Apart from that, Moldavan students were not fully aware about the difference between authentic texts and non-authentic ones: they simply never questioned this aspect of instructional contents, though some admitted that they enjoy learning English more from materials other than the ones in the course book. There is also a high probability that the considerable number of those who answered undecided did so because they either have no prior experience learning EFL from LT or because it has no relevance to them. Some of the surveys contained corrected answers which could serve as an argument for this viewpoint. Presumably, the students should have been provided some more information about the different types of texts and what is encompassed under the category LT to ensure they provided well-informed answers. 


\section{Conclusions and suggestions}

Although specialized literature in the field of EFL has witnessed a significant increase of awareness related to the need of integrating literary texts in the language curriculum, there is still much reluctance to do so, more so on the part of stakeholders and sometimes teachers as well.

This survey attempted to identify students' perceptions about incorporating LT as part of their communicative EFL university courses and it revealed that students at "Ion Creangă" Pedagogical University favor it more eagerly that those at UGR, which serves as a strong impetus for implementing a literature-based language learning project. Discussions held on a later date, after some short stories have been covered through different approaches like reader response approach, transactional approach, and inquiry-based approach, revealed that students feel they gain a lot from interacting with representational texts in terms of intercultural, linguistic, discourse, and metaphorical competences than from exploiting just referential texts. All these findings alongside the valuable ones presented in the specialized literature should be taken into account and some course curricula, at least, should incorporate literature as a source of input.

\section{References}

- Aghagolzadeh, F. (2012). A Debate on Literature as a Teaching Material in FLT. Journal of Language Teaching and Research, 3(1), 205-210. https://doi.org/10.4304/jltr.3.1/205-210.

- Alemi, M. (2010). Literature in the EFL/ESL Classroom. Consensus and Controversy. Linguistic and Literary Broad Research and Innovation, 1(1), $1-12$.

- Alemi, M., \& Pashmforoosh, R., (2013). EFL Teachers' Self-efficacy Beliefs in Teaching Literature. The International Journal of Literacies, 19(2), 25-36. https://doi.org/10.18848/2327-0136/cgp/v19i02/48770.

- Amer. (2003). Teaching EFL/ESL Literature. The Reading Matrix. 3(2), 63-73.

- Bobkina, H., \& Dominguez, E. (2014). The Use of Literature and Literary Texts in the EFL Classroom; Between Consensus and Controversy. International Journal of Applied Linguistics \& English Literature, 3(2), 248-261. https://dx.doi.org/107575/aiac.ijalel.v.3n.2p.248. 
- Collie, J., \& Slater, S. (1987). Literature in the Language Classroom: A Resource Book of Ideas and Activities. Cambridge: Cambridge University Press.

- Costello, J. (1990). Promoting Literacy through Literature: Reading and Writing in ESL Composition. Journal of Basic Writing, 9(1), 20-31.

- Crystal, D. (2003). English as a global Language. New York: Cambridge University Press.

- Das, B.B. (2014). Literature - a Pedagogic Tool: a Defense. International Journal of Humanities and Social Science Invention, 3(9), 10-18.

- Duff, P. A. (2001). Language, Literacy, Content and (Pop) Culture: Challenges for ESL Students in Mainstream Courses. The Canadian Modern Language Review, 58(1), 103-132.

- Erkaya, O. R. (2005). Benefits of Using Short Stories in the EFL Context. Asian EFL Journal, 8, 2-15.

- Gajdusek, L. (1988). Toward wider use of literature in ESL: Why and How. TESOL Quarterly, 22, 227-254.

- Khatib, M. (2011a). Some Recommendations for Integrating Literature into EFL/ESL Classrooms. International Journal of English Linguistics, 1(2), 258-263.

https://doi.org/10.5539/ijel.v1n2p258.

- Khatib, M., Derakhshan, A., \& Rezaei, S. (2011). Why \& Why Not Literature: A Task-Based Approach to Teaching Literature. International Journal of English Linguistics, 1(1), 213-218. https://doi.org/10.5539/ijel.v1n1p213.

- Lazar, G. (1996). Exploring Literary Texts with the Language Learner. TESOL Quarterly, 30(4), 773-776.

- Lazar, G. (1993). Literature and Language Teaching. Cambridge, UK: Cambridge University Press.

- McKay, S. (2001). Literature as content for ESL/EFL. In M. Murcia (Ed.), Teaching English as a Second/Foreign Language (pp. 319-331). Boston: Heinle \& Heinle.

- McRae, J. (1996). Representational Language Learning: from Language Awareness to Text Awareness. In Carter, Ronald \& John McRae (Eds.), Language, Literature and the Learner: Creative Classroom Practice, 16-41, Pearson Education Ltd.

- Moecharam, N.Y., \& Kartika Sari, A. (2014). Let's Talk and Tolerate Strengthening Students' Cultural Awareness through Literature Circles. Indonesian Journal of Applied Linguistics, 3(2), 117-127.

http://dx.doi.org/10.17509/ijal.v3i2.662.

- Ortells, E. (2013). Teaching English as a Foreign Language in Spanish Secondary Schools: The value of Literature. English Teaching: Practice and Critique. 12(1), 91-110. 
- Paran, A. (2006). Literature in Language Teaching and Learning. Case Studies in TESOL Practice Series. Alexandria.

- Savvidou, Ch. (2004). An Integrated Approach to Teaching Literature in the EFL Classroom. Retrieved from: http://iteslj.org/Techniques/SavvidouLiterature.html

- Sivasubramaniam, S. (2006). Promoting the Prevalence of Literature in the Practice of Foreign and Second Language Education: Issues and Insights. Asian EFL Journal, 8(4), 254-273.

- Van, T.T. (2009). The Relevance of Literary Analysis to Teaching Literature in the EFL Classroom. Forum, 3, 2-9.

- Xerri D., \& Xerri St. (2012). The Use of Literature in ELT. ETAS Journal, 30(1), 18-23.

The online version of this article can be found at: http://revped.ise.ro/category/2019-en/

\section{(CC) BY-NC-SA}

This work is licensed under the Creative Commons Attribution-NonCommercial-ShareAlike 4.0 International License.

To view a copy of this license, visit http://creativecommons.org/licenses/by-nc-sa/4.0/ or send a letter to Creative Commons, PO Box 1866, Mountain View, CA 94042, USA.
Versiunea online a acestui articol poate fi găsită la: http://revped.ise.ro/category/2019-ro/

\section{(cC) BY-NC-SA}

Această lucrare este licen iată sub Creative Commons Attribution-NonCommercial-ShareAlike 4.0 International License.

Pentru a vedea o copie a acestei licen e, vizita $i$ http://creativecommons.org/licenses/by-nc-sa/4.0/ sau trimite i o scrisoare către Creative Commons, PO Box 1866, Mountain View, CA 94042, SUA. 